\title{
Chemical Analysis of Hair Segments and Short-Term Dietary Variation: Results for the Ancient Site of Chongos (Peru)
}

\author{
R.H. Tykot, A. Metroka, M. Dietz, and R.A. Bergfield
}

\section{Introduction}

One of the major questions about pre-Inca societies in Peru and other areas of South America is the spread and importance of maize agriculture and its relationship with the development of complex societies. While archaeological studies to answer dietary questions have long been done on faunal and floral remains, chemical analysis of human remains has provided quantitative data on the importance of particular foods for individuals, and thus potential variation in dietary patterns based on sex, age, status, etc. The majority of such studies have been done on human bone, due to preservation issues, with the results referring to average diets over at least the last several years of the individual's life.

In this study, preserved hair samples from seven individuals at the Early Horizon Early Intermediate Period site of Chongos (Pisco River Valley, Peru) were tested in segments in order to look at short term dietary variation. The stable carbon and nitrogen isotope analysis data demonstrate significant short-term dietary variation in the consumption of both seafood and $\mathrm{C} 4$ plants such as maize, as well as variation among individuals.

\section{Chongos (Peru) Archaeological Site}

Chongos is located in the Pisco river valley on the outskirts of Pisco, north of Paracas (Fig. 1). The site is approximately $1 \mathrm{~km}$ south of the Pisco river, and about $12 \mathrm{~km}$ from the Pacific coast. It was excavated by a team of Peruvian and U.S. archaeologists in the mid to late 1980s as a salvage operation sponsored by the National Institute of Culture in Peru (Peters 1987/1988; 1997). The Chongos site

\footnotetext{
R.H. Tykot $(\bowtie)$ and A. Metroka

Department of Anthropology, University of South Florida, Tampa, FL 33620, USA

e-mail: rtykot@cas.usf.edu

M. Dietz and R.A. Bergfield

Department of Anthropology, University of Missouri-Columbia, Columbia, MO 65211, USA
} 


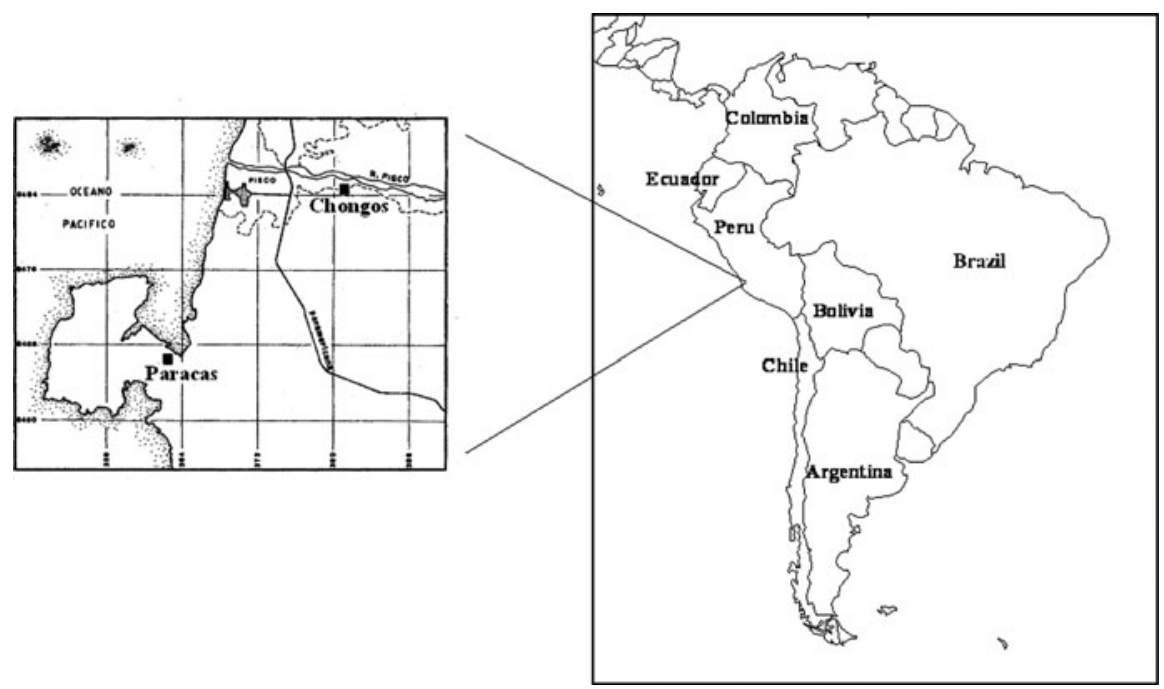

Fig. 1 Map showing location of the site of Chongos, near the Pisco River, north of Paracas on the coast of Peru

contains components that correspond to both the Paracas and Topará traditions during the Early Horizon/Early Intermediate Period (ca. 2300-1700 BP), meaning that the site was perhaps occupied at different times by people from different cultures over a relatively short period of time.

Chongos was likely an agricultural village, with an adjacent cemetery. The burials recovered at Chongos may or may not reflect a social community, with individuals from one place. So while they came from a similar time period, the cemetery may have included individuals associated with both the Paracas and Topará traditions, coming from different sites and different communities.

By the Horizon Period in Peru, formal agriculture and animal husbandry was well organized, so a broad menu including freshwater and marine fish and shellfish would have been available (e.g. Tykot and Staller 2002). Plant food items actually recovered at Chongos include peanuts, maize, sweet potato and manioc.

Human remains excavated at Chongos range from fully mummified to completely skeletonized individuals (Fig. 2). While full osteological investigation was not possible for those with soft tissues preserved, it was clear that Chongos people had a very high caries rate, a high rate of systemic infection, and a high rate of cribra orbitalia, but no external auditory exostoses (Dietz, forthcoming).

\section{Hair Sample Preparation and Stable Isotope Analysis}

The preservation of hair samples at Chongos specifically allowed us to do stable isotope analysis on individuals without being destructive to the skeletal remains, and at the same time investigate short-term, i.e. monthly, dietary variation 

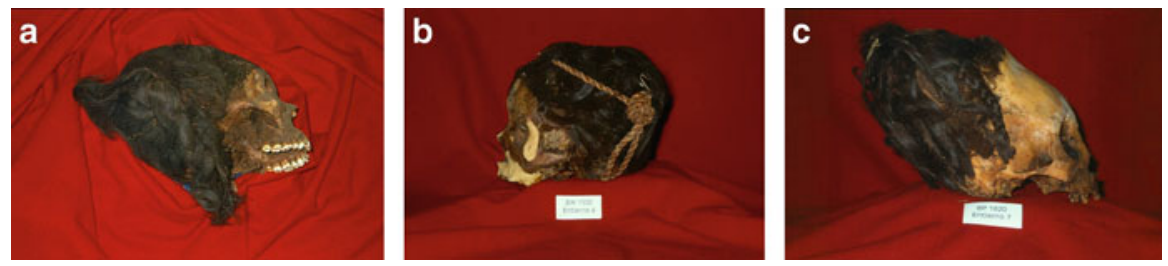

Fig. 2 Examples of skulls found at Chongos. Above left: adult male with braided hair, and cranial deformation typical' of Paracas. Above center: adult female from Chongos, location BW 1500, burial 4. Above right: skull of a child age 5-6, location BP 1820, burial 7, with braided hair and Paracas style cranial deformation

(see Tykot 2004, 2006 for principles and history of stable isotope analysis). Hair samples had already been studied separately, using elemental analysis (Bergfield 2007). Because the hairs were in many cases still attached to the cranium, it was possible to obtain several adjacent hairs for each individual and maintain their alignment. After cleaning to remove any contaminants, samples were then cut in one-centimeter segments, with enough mass $(1 \mathrm{mg})$ to provide both $\mathrm{C}$ and $\mathrm{N}$ isotope results. The comparison of $1 \mathrm{~cm}$ segments were expected to show monthly dietary variation.

The 1-cm length hair segment samples were weighed into tin cups, and analyzed on a Finnigan MAT Delta Plus XL stable isotope mass spectrometer in the Paleolab at the University of South Florida, using a Costech CHN multi-sampler. C and N gas yields as well as $\mathrm{C}: \mathrm{N}$ ratios were used to determine the reliability of the results. The precision of the analyses were $0.1 \%$ o for $\mathrm{C}$ and $0.2 \%$ for $\mathrm{N}$, and the isotope values reported are relative to the VPDB and AIR standards, respectively. The isotope data for the hair segments is provided in Table 1.

\section{Discussion}

The range and overall average isotope values $\left(\delta^{13} \mathrm{C}=-15.1 \forall 2.5 \%\right.$; $\delta^{15} \mathrm{~N}=12.2$ $\forall 3.3 \%$ ) for the seven individuals tested overlap with those obtained for other precontact period sites in Peru, e.g. highland sites including Chavín de Huantar (Burger and van der Merwe 1990), Conchopata (Finucane et al. 2006), Pacopampa (Tykot et al. 2006), and the Ayacucho Valley (Finucane 2007), and lowland/coastal sites including the Virú Valley (Ericson et al. 1989), Pacatnamu (Verano and DeNiro 1993), the Osmore Valley (Tomczak 2003), Mina Perdida and the Lurin Valley (Tykot et al. 2006), and San Geronimo, Chirabaya Alta, Chirabaya Baja, and El Yaral in the Osmore Valley (Tomczak 2003; Knudson et al. 2007). Unlike those other sites, especially for the time period represented by Chongos, there is much greater variation among these individuals, as is clear from the standard deviation values. 
Table 1 Stable isotope data for hair segments from seven Chongos individuals

\begin{tabular}{|c|c|c|c|c|c|c|c|c|}
\hline Ind. & Segment & $\begin{array}{l}\text { USF } \\
\#\end{array}$ & $\delta^{13} \mathrm{C}$ & $\delta^{15} \mathrm{~N}$ & $\begin{array}{l}\delta^{13} \mathrm{C} \\
\text { Range }\end{array}$ & $\begin{array}{l}\delta^{13} \mathrm{C} \text { average/ } \\
\text { std }\end{array}$ & $\begin{array}{l}\delta^{15} \mathrm{~N} \\
\text { Range }\end{array}$ & $\begin{array}{l}\delta^{15} \mathrm{~N} \text { average/ } \\
\text { std }\end{array}$ \\
\hline 12 & 1 & 10006 & -16.7 & 12.6 & & & & \\
\hline 12 & 2 & 10007 & -16.8 & 14.4 & & & & \\
\hline 12 & 3 & 10008 & -17.8 & 14.3 & & & & \\
\hline 12 & 4 & 10009 & -17.2 & 13.4 & 1.1 & $-17.1 \forall 0.4$ & 1.7 & $13.7 \forall 0.7$ \\
\hline 18 & 1 & 10010 & -17.4 & 7.0 & & & & \\
\hline 18 & 2 & 10011 & -17.1 & 7.4 & & & & \\
\hline 18 & 3 & 10012 & -16.9 & 8.3 & & & & \\
\hline 18 & 4 & 10013 & -16.6 & 9.9 & & & & \\
\hline 18 & 5 & 10014 & -15.8 & 10.9 & 1.6 & $-16.8 \forall 0.5$ & 4.0 & $8.7 \forall 1.5$ \\
\hline 30 & 1 & 10015 & -17.4 & 15.9 & & & & \\
\hline 30 & 2 & 10016 & -17.8 & 15.1 & & & & \\
\hline 30 & 3 & 10017 & -17.8 & 15.9 & & & & \\
\hline 30 & 4 & 10018 & -17.2 & 16.1 & & & & \\
\hline 30 & 5 & 10019 & -16.4 & 16.7 & 1.4 & $-17.3 \forall 0.5$ & 1.6 & $15.9 \forall 0.5$ \\
\hline 40 & 1 & 10020 & -11.9 & 16.8 & & & & \\
\hline 40 & 2 & 10021 & -11.5 & 16.5 & & & & \\
\hline 40 & 3 & 10022 & -12.0 & 15.2 & & & & \\
\hline 40 & 4 & 10023 & -13.0 & 12.6 & 1.5 & $-12.1 \forall 0.5$ & 4.2 & $15.3 \forall 1.7$ \\
\hline 47 & 1 & 10024 & -12.0 & 13.8 & & & & \\
\hline 47 & 2 & 10025 & -12.7 & 13.8 & & & & \\
\hline 47 & 3 & 10026 & -12.8 & 13.9 & & & & \\
\hline 47 & 4 & 10027 & -13.2 & 13.5 & 1.2 & $-12.7 \forall 0.4$ & 0.4 & $13.8 \forall 0.1$ \\
\hline 51 & 1 & 10028 & -16.8 & 8.1 & & & & \\
\hline 51 & 2 & 10029 & -18.1 & 7.2 & & & & \\
\hline 51 & 3 & 10030 & -15.4 & 8.2 & & & & \\
\hline 51 & 4 & 10031 & -14.5 & 8.1 & & & & \\
\hline 51 & 5 & 10032 & -15.7 & 7.7 & & & & \\
\hline 51 & 6 & 10033 & -17.8 & 8.0 & & & & \\
\hline 51 & 7 & 10034 & -17.5 & 8.2 & 3.6 & $-16.5 \forall 1.3$ & 1.0 & $7.9 \forall 0.3$ \\
\hline 52 & 1 & 10035 & -14.1 & 12.2 & & & & \\
\hline 52 & 2 & 10036 & -11.9 & 13.3 & & & & \\
\hline 52 & 3 & 10037 & -10.2 & 14.1 & & & & \\
\hline 52 & 4 & 10038 & -10.1 & 14.7 & 4.1 & $-11.6 \forall 1.6$ & 2.5 & $13.6 \forall 0.9$ \\
\hline
\end{tabular}

Like other studies of human hair in South America (Tykot et al. 2006; Shelnut 2006; Gil et al. 2006; Knudson et al. 2007), there is also clearly significant shortterm variation for each of the individuals tested at Chongos (Fig. 3). One can immediately see that two individuals $(18,51)$ have low nitrogen isotope values, indicating a mostly terrestrial diet. But individual 18 has short-term variation in which both $\mathrm{C}$ and $\mathrm{N}$ isotope values increase, suggesting seasonal variation in seafood consumption. Individual 51, on the other hand, has short-term variation only in the carbon isotope values, most likely from seasonal maize consumption.

Individuals 12 and 30 have fairly low carbon isotope values but much higher nitrogen isotope values, clearly indicating major consumption of freshwater fish, with individual 12 appearing at times to have some maize in the diet. Individuals 40 , 47, and 52 have very high carbon and nitrogen isotope values in their hair segments, clearly indicating major consumption of higher trophic level marine foods. 


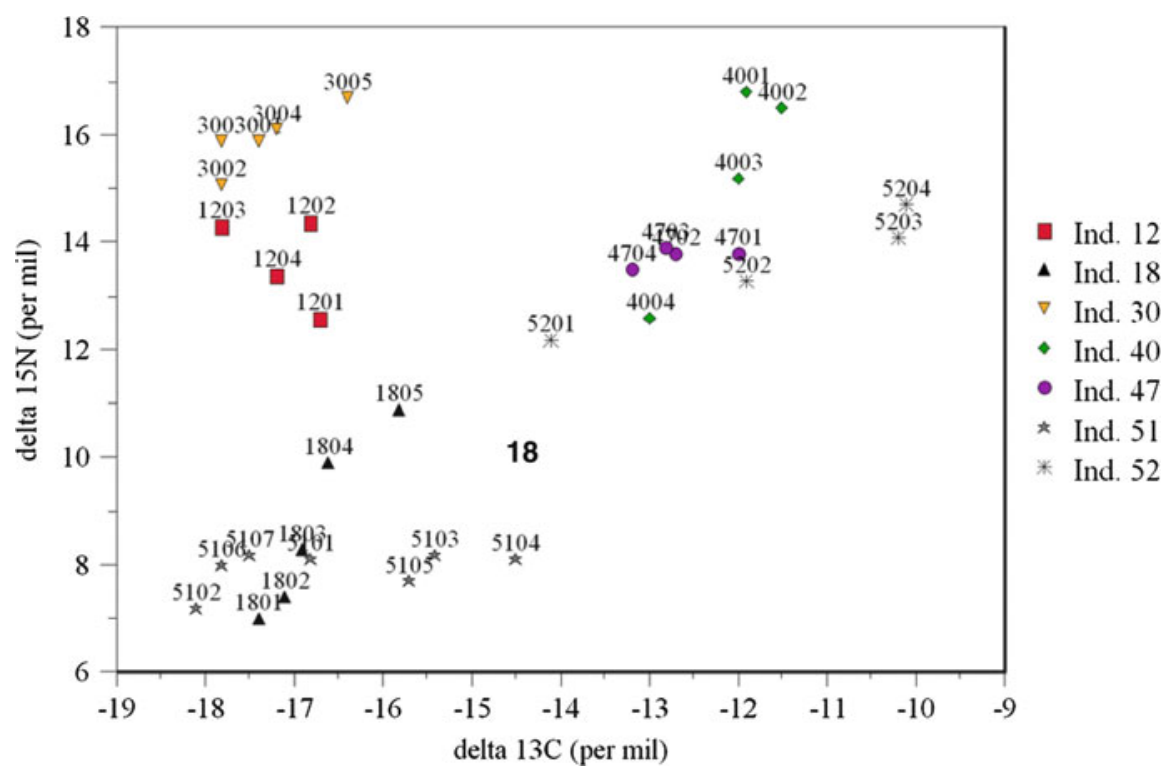

Fig. 3 Carbon vs. nitrogen stable isotope data for hair segments of seven individuals from Chongos, Peru

\section{Conclusion}

There clearly were major differences in diet in general, and in seasonal practices, between the seven individuals tested at Chongos. Overall, the variation in the isotope data and the diets they represent is due either to individual and/or political choice, and raises socioeconomic questions about food acquisition and production, labor organization, and exchange that developed in Peru by the Early Horizon/Early Intermediate Period. Could individual 18 be a traveler between highlands and lowlands thereby consuming plants and fish? Were individuals 30 and 40 strictly lowland dwellers that consumed mainly what was caught from a water source? In particular, this dietary variation supports our hypothesis that these burials may well represent a mixture of people at Chongos, some affiliated with Paracas, and others who are affiliated with Toparà, and thus serves as a catalyst for additional research. The results obtained here will be integrated further with the archaeological, osteological and elemental analyses done, to further understand this important period in ancient Peru.

Acknowledgments This research was initiated by Prof. Robert Benfer, Department of Anthropology, University of Missouri-Columbia, and supported by a USF Honors College award to Anne Metroka for her senior honors thesis research. We also thank Dr. David Hollander and Ethan Goddard for directing the Paleolab and running these samples on the mass spectrometer. 


\section{References}

Bergfield RA (2007) Dietary analysis of archaeological hair samples from Peru. MA Thesis, University of Missouri-Columbia

Burger RL, van der Merwe NJ (1990) Maize and the origin of highland Chavín civilization: an isotopic perspective. Am Anthropol 92:85-95

Ericson JE, West M, Sullivan CH, Krueger HW (1989) The development of maize agriculture in the Viru Valley, Peru. In: Price TD (ed) The chemistry of prehistoric human bone. Cambridge University Press, Cambridge, pp 68-104

Finucane BC (2007) Mummies, maize, and manure: multi-tissue stable isotope analysis of Late Prehistoric human remains from the Ayacucho valley, Peru. J Archaeol Sci 34:2115-2124

Finucane B, Agurto PM, Isbell WH (2006) Human and animal diet at Conchopata, Peru: stable isotope evidence for maize agriculture and animal management practices during the Middle Horizon. J Archaeol Sci 33:1766-1776

Gil A, Shelnut N, Neme G, Tykot RH, Michieli T, Teresa C (2006) Isotopos estables y dieta humana en el centro oeste: datos de muestras de San Juan. Cazadores Recolectores Sudamericanos 1:151-163

Knudson KJ, Aufderheide AE, Buikstra JE (2007) Seasonality and paleodiet in the Chiribaya polity of southern Peru. J Archaeol Sci 34:451-462

Peters AH (1987/1988) Chongos: sitio Paracas en el valle de Pisco. Gaceta Arqueologica Andina 16:30-34

Peters AH (1997) Paracas, Topara and Early Nasca: ethnicity and society on the South Central Andean Coast. PhD dissertation, Cornell University

Shelnut N (2006) Prehistoric subsistence patterns in Western Argentina. MA Thesis, University of South Florida

Tomczak PD (2003) Prehistoric diet and socioeconomic relationships within the Osmore Valley of southern Peru. J Anthropol Archaeol 22:262-278

Tykot RH (2004) Stable isotopes and diet: you are what you eat. In: Martini M, Milazzo M, Piacentini M (eds) Physics methods in archaeometry, Proceedings of the international school of physics "Enrico Fermi”" course CLIV. Società Italiana di Fisica, Bologna, Italy, pp 433-444

Tykot RH (2006) Isotope analyses and the histories of maize. In: Staller JE, Tykot RH, Benz BF (eds) Histories of maize: multidisciplinary approaches to the prehistory, linguistics, biogeography, domestication, and evolution of maize. Academic Press (Elsevier), Amsterdam, Netherlands, pp 131-142

Tykot RH, Burger R, van der Merwe NJ (2006) The importance of maize in initial period and early horizon Peru. In: Staller JE, Tykot RH, Benz BF (eds) Histories of maize: multidisciplinary approaches to the prehistory, linguistics, biogeography, domestication, and evolution of maize. Academic Press (Elsevier), Amsterdam, Netherlands, pp 187-197

Tykot RH, Staller JE (2002) The importance of early maize agriculture in coastal Ecuador: new data from La Emerenciana. Curr Anthropol 43:666-677

Verano JW, DeNiro MJ (1993) Locals or foreigners? Morphological, biometric, and isotopic approaches to the question of group affinity in human skeletal remains recovered from unusual archaeological contexts. In: Sandford MK (ed) Investigations of ancient human tissue: chemical analysis in anthropology. Gordon and Breach Science Publishers, Langhorne, PA, pp 361-86 